\title{
"HENDERSON: FROM CHAOS TO CLARITY" *
}

\author{
Sigrid P. M. L. S. Renaux **.
}

INTRODUCTION

1 - MANIFESTATIONS OF CHAOS: Proliferation of things

Clowning, fooling and madscenes

The horror of death

Lonesomeness

The absurd seeker of high qualities

II - MANIFESTATIONS OF CLARITY: Does truth come in blows?

Prowess and nobility

Grun-tu-molani, but in what form?

African sunrise and Arctic day-

CONCLUSION light

\section{INTRODUCTION:}

When William Faulkner received the Nobel Prize in literature in Stockholm in 1950, he declared: "He [the writer] must teach himself that the basest of all things is to be afraid; and, teaching himself that, forget it forever, leaving no room in his workshop for anything but the old verities and truths of the heart, the old universal truths, lacking which any story is ephemeral and doomed - love and honor and pity and pride and compassion and sacrifice".

It is exactly this search for the universal truths that Saul Bellow has put in the mind of his most autobiographical creation, Eugene Henderson. This attempt Henderson makes to undersland the "infinitely elusive universe" ${ }^{1}$ ), this quest for reality in human destiny gives him the energy to leave America's supercivilization and the

(*) Trabolho opresentado ao Professor do Literatura Americana: Fiç̧ão Pós.Guerra, Prof. Dr. CLYDE ENROIH, como requisito para obtençäo de créditos. Juntio de 1972.

(*) Aluna de Pós-Graduaḡōo em Estudos Anglo-Americunas. Dept. de Letras Estrangeiras Modernas, Universidade de Sāo Paulo. 
"disorderly rush" (") he has got into, to find the answer to his inner voice "I want, I want" in an Africa undiscovered by man.

As Jonathan Baumbach says in The Landscape of Nightmare (3), "Bellow's longer fiction readily divides itself into two main groups: the novels of depth, of claustrophobic internal exploration, influenced by Dostoievsky (Dangling Man, The Victim, and Seize the Day), and the novels of breadth, of sensation and experience, of physical and spiritual quest (The Adventures of Augie March and Henderson the Rain King). Inevitably - [Baumbach concludes] - since Bellow is not two men, the preoccupations of each group reside to some extent in the other". So one sees that the physical experiences Henderson undergoes in Africa are accompanied by changes in his spirit, for an external exploration is followed by an internal exploration, in an "Africa of the spirit" (").

Going to Africa with Henderson, we are on a guided tour of life, for Bellow writes in the same tradition of the romance novel as the great American writers, Melville, Hawthorne, and Faulkner. What sets Bellow apart from his contemporaries is exactly that the belief about life that shapes the book is optimistic, not pessimistic. Henderson is a collector of experiences, just like Mr. Sammler in Mr. Sammler's Planet, but the experiences he gathers in Africa make him turn from a "Becomer" into a "Be-er".

The novel might be divided into two parts: the chaos of civilized life in America and Europe, and the clarity of primitive life in Africa.

\section{1 - MANIFESTATION OF CHAOS:}

Examining the several aspects of Henderson's hectic life in America, and his attitude towards it, we come to the conclusion that the same themes found in the modern novel are also found in the Theatre of the Absurd.

\section{Proliferation of things:}

As Henderson himself states at the beginning of the story, "The facts begin to crowd me and soon 1 get a pressure in the chest. A disorderly rush begins - my parents, my wives, my music lessons, my drunkenness, my prejudices, my brutality, my teeth, my face, my soul! I have to cry, No, no, get back, curse you, let me alone! But how can they let me alone? They belong to me. They are mine. And they pile into me from all sides. It turns into chaos". ("). The accumulating junk in his life is double: material and spiritual. 
-If we compare this junk to the proliferation of things we find in lonesco's plays The Chairs and The Future is Egg, in which the stage is invaded by evergrowing masses of people or things, we understand Henderson's and the individual's horror "at being confronted with the overwhelming task of coping with the world, his solitude in the face of its monstrous size and durations" (").

\section{Clowning, fooling and mad-scenes:}

Henderson easily gets into brawls and fights, he feels bitter and restless. "I, too, am considered crazy, and with good reason moody, rough, tyrannical, and probably mad" (i). He acts like a madman, on purpose, like when his second wife Lily is entertainning ladies and he comes in wearing a red velvet dressing gown, a red wool hunting cap, besides his filthy plaster cast on his leg and sweat socks, and wipes his nose and mustache on his fingers and then shakes hands with the guests, including Lily, as if she were merely another guest, like the others. This is pure Absurd Theatre.

As Henderson himself says, he transformed his beautiful old farm into a pig kingdom, to illustrate what he thought of life in general. He dramatized what he felt about the universe: no better than a pig farm for him.

\section{The horror of death:}

Behind the "satirical exposure of the absurdity of inauthentic ways of life", Henderson faces a "deeper layer of absurdity - the absurdity of the human condition itself in a world where the decline of religious belief has deprived man of certainties" (s). That is why we see Henderson rebelling against death, confronting and accepting it (s).

The experience he has with the octopus he sees in an aquarium in Banyules conveys a sense of "cosmic coldness" ( $\left({ }^{(1)}\right.$ to him: "The creature seemed also to look at me and press its soft head to the glass, flat, the flesh becoming pale and granular - blanched, speckled. The eyes spoke to me coldly. But even more speaking, even more cold, was the soft head with its speckles, and the Brownian motion in those speckles, a cosmic coldness in which 1 felt I was dying. The tentacles throbbed and motioned through the glass, the bubbles sped upward, and I thought, 'This is my last day'. Death is giving me notice" (11). A similar image is found in Fellini's La Dolce Vita where the sea monster seen at the beach also conveys this sense of the horror of a depraved world. 
Although Henderson rejects this vision of death, for he feels repulsed by it, he soon finds himself facing another one. The sec ond experience is related to the death of Miss Lenox, the old woman who helped in the kitchen of his farmhouse. Feeling somewhat guilty for her death (from a heart aftack) because he had been yelling at Lily, Henderson goes to Miss Lenox's cottage and is shocked by the rubbish he finds there: "Bottles, lamps, old butter dishes, and chandeliers were on the floor, shopping bags filled with string and rags, and pronged openers that the dairies used to give away"...; "and bushel baskets full of buttons and china door knobs. And on the walls, calendars and pennants and ancient photographs". (12). And Henderson thinks:.. "make a move, Henderson, fut forth effort. You, 100, will die of this pestilence. Death will annihilate you and nothing will remain, and there will be nothing left but junk" (13). So Henderson leaves for Africa, fleeing from the horror of death and the complication of things.

\section{Lonesomeness:}

Another aspect Henderson has in common with the themes of the Absurd Theatre is his lonesomeness: "Man forever lonely, immured in the prison of his subjectivity, unable to reach his fellowman"

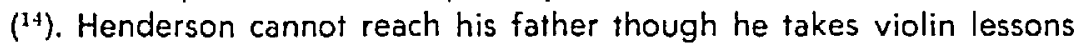
to feel near him; he cannot reach his own son, nor his wives, nor his daughter, nor his friend Charlie with whom he goes to Africa, nor even the cat his tenants had forgotten and which he wants to shoot down (compare to Edward Albee's "The Zoo Story", in which Jerry is unable to establish genuine contact with a dog).

\section{The absurd seeker of high qualities:}

Bellow himself has defined Henderson thus, in an interview. Henderson is a mixture of the romantic, absurd and anti-hero. From the tratitional romantic hero he inherits his millions, his titanic size ("slrong, healthy, rude, aggressive") ${ }^{\left({ }^{15}\right)}$, his distinguished American forefathers, his un-Jewishness. From the absurd hero Henderson inherited his search for his real self, his flight from the tentacles of the proliferation of civilized society, his furbulence of spirit, his search for depth, for he cannot fathom society, he cannot see its bottom, as he did when he exploded the water reservoir of the Arnewi. And from the anti-hero or picaresque hero, he inherits his common way of speaking, his curses, his "enormous head, suspicious eyes, blustering ways, a great nose, often drunk before lunch" $\left({ }^{10}\right)$, a creator of pigs, almost a loafer, no better than the reader himself. 
- We see from these instances the close relationship there is between the modern novel and the Theatre of the Absurd, as to their themes. But a main point in which they do not agree is in the existencialist belief that "man is nothing because he has the liberty of choice and therefore is always that which he is in the process of choosing himself to be, a permanent potentiality rather than an actual being" ("17): Henderson, on the other hand, moves from his chaotic world of "becoming" to the Arctic clarity of "being".

So, Bellow grants the absurd premises that human experience is apparently unredeemable, that we are confronted with the dilemma of who will emerge victorious - man or environment - which impulses will domiricte the individual - the humanistic or the nihilistic but he denies the conventional alssurd conclusions, that man cannot resist despair, for Bellow believes in man's ability to establish a "new secular hurianism" (15).

\section{II - MANIFESTATIONS OF CLARITY:}

\section{Does truth come in blows?:}

Even before leaving Africa, Henderson has already some glimpses of truth - while chopping wood in his farm, a log hits his face and as he feels the blow his only thought is "truth" $\left({ }^{19}\right)$. And he realizes that "here always comes a day of tears and madness" (") while the voice in him crying "I want! I want!" goes on, through fights and drunkenness and labour, in the country, in the city. So Henderson comes to the conclusion that "in an age of madness, to expect to be untouched by madness is a form of madness. But the pursuit of sanity can be a form of madness, too" (21).

Henderson's object in going to Africa was "to leave certain things behind" ("-), so he parts from Charlie and his wife - who remind him of his complicated life in his anxiety to "simplify more and more" ("-3). And with only one guide, Romilayu, who sarves him as guide, interpreter, confessor and friend, Henderson reaches the Arnewi village, "older than the city of Ur"... (24).

There he receives another blow of truth: the villagers who receive him burst into tears at his sight, wounding Henderson deeply, for he thinks the blame lies on himself, on his fierce aspect, for although he already felt a change in himself since he arrived in Africa, it seemed he still was not ready for society. "Society is what beats me. Alone I can be pretty good, but let me go among people and there's the devil to pay" $("-5)$. But when Romilayu tells him they 
were crying because of their dying cattle, Henderson strikes himself in the head with his open hand and says: "Why sure"!... "I would think first of myself" $(20)$. And he realizes for the first time that the voice inside himself, crying "I want", can also listen to other people crying "I want". His selfishness in suffering receives a blow, for he sees he is not the only one to be suffering, and immensely relieved, he understands something can be done to help these poor people.

Meeting Itelo, the Arnewi king, Henderson is surprised to be addressed in English, for he was so sure he had left the world, and here was someone "who had obviously been around" ("i $)$. Henderson feels the ridiculousness of his situation, his disappointment at finding out he is not the first white man to reach that ancient bed of man. kind. Itelo tells him: "You thought first footstep? something new? I am very sorry. We are discovered" ((-") $)$. This ironic twist sets the novel straight back into the modern line, for it was getting too romantic.

Another blow of truth Henderson has is when he finds out that absurdities exist everywhere, even in this antique place: the Arnewi couldn't let their cattle drink water from the cistern because there were frogs inside it and their custom forbids them "to touch animal in drink wattah" ("9). Henderson shakes his head much more at himself than at them, thinking that "damned fool going out into the world is bound and fated to encounter damned fool phenomena" (3i").

Wrestling with Prince Itelo, "to make acquaintance" (" $\left.{ }^{31}\right)$ in a ritual gesture, Henderson falls on his front, with such force, that he thinks he has split himself upward from the navel. Taking advantage again of this experience, he realizes once more that only the blows of truth can "burst my spirit's sleep" ("3").

To regain Itelo's respect, Henderson must activate himself, and decides to wrestle him after all. Henderson had fled civilization because he couldn't fight it on its own terms, but even here in Africa, he realizes there are moments when you can't just turn your back to but you must fight.

Another step towards clarity and order is given. But Henderson knows he has won not only because of "mere bone and muscle" ( ${ }^{(3)}$ ) but that it was a question of spirit, too: he has always struggled "without rest" (34) for his strength wasn't a "happy strenght" ("3i). "Take it from me", he tells itelo, "you are a better man" $\left({ }^{36}\right)$. 


\section{Prowess and nobility:}

If before coming to Africa Henderson excelled in terrifying others with his absurdities and mad-scenes, now he does his best in proving to the Arnewi and later to the Wariri that, to burst his spirit's sleep and carry his life to a certain depth, he must "discover that service which, performed, may be the human retort to death" $\left.{ }^{37}\right)$.

Trying to impress the Arnewi with his prowess - besides his humanitarian feelings for them - Henderson wants to kill the frogs by polluting the cattles drinking water. At night, preparing to exterminate them, Henclerson was gloating, his heart already "fattening in anticipation of their death. We hate death, we fear death, bul when you get right down to cases, there's nothing like it" ("3i).

Henderson hungered to let fall "the ultimate violence" ("in) $\mathrm{cn}$ these creatures, as if by killing these thousands of little images ot death for the Arnewi, he would be annihilating the image of the octopus that had taken hold of his life. Once more, he was "fatally embroiled with animals, according to the prophecy of Daniel which he had never been able to shake off - "They shall drive you from among men, and thy dwelling shall be with the beasts of the field" $\left({ }^{40}\right)$. He remembers his involvement with pigs and the cat, and feels a tremendous sorrow. But here it is clear, he is going to kill the frogs for a purpose, not like with the cat, where his basic motivation had gone wrong.

And he turns with confidence to preparing the bomb, while speaking to Romilayu: "Hah! Life may think it has got me written off in its records"... "But life may find itself surprised, for after all, we are men. I am Man - I myself, singular as it may look. Man. And man has many times trciked life when life thought had him taped" (11). It is a triple revenge Henderson is taking: against the frogs, against the octopus, against the tricks of life.

But reality has another blow in store for Henderson, for, by exterminating the frogs with his bomb, he also explodes the walls of the cistern and all the water pours out, emptying the Arnewi's water supply to the ground. In the chaotic riot that follows, Henderson in his despair covers his face with his $T$ shirt and melodramatically awaits death. But death does not come, for Itelo is too noble and the Arnewi are too meek to kill him, so Hienderson leaves, for it is "the best contribution" ("2) he can make to them now. The devices of civilized man are useless in such a place where life has to be met on a more basic and primitive level. 
It is among the second tribe that Henderson visits, the Wariri, that he has occasion to demonstrate his prowess and strength, and where he learns the real meaning of nobility. Much more aggressive than the Arnewi (perhaps because they were more advanced culturally they were also fiercer than the Arnewi (does civilization brutalize men?), the Wariri immediately strip Henderson of all his civilized possessions, except his clothes.

Left alone with Romilayu in a hut at night, Henderson finds a corpse in their room. He feels the dead man is sending him a message such as "Here, man, is your being, which you think so terrific" (43). Horribly stirred, Henderson decides to drag him out of the hut (he continues to run from death) and throws it with Romilayu's help into a ravine, only to find the corpse in the hut again, after their return.

Doing this feat of prowess, Henderson is actually just avoiding contact with death: he had fled from the octopus as he had fled from the dead old lady's junk, but this time, the dead man is brought back from the ravine, just like a Lazarus. While feeling repugnance and anger at carrying him, Henderson had thought: "What if this man is a Lazarus? I believe in Lazarus. I believe in the awakening of the dead. I am sure that for some, at least, there is a resurrection"... "But this dead man on my back was no Lazarus. He was cold and the skin in my hands was dead" (").

But Henderson's belief is deeply shaken when he is confronted with the same dead man again - another ironic fwist of Bellow's.

Undoubtedly, Henderson's biggest feat of prowess is lifting the statue of Mummah, the goddes of the clouds, which transforms him into the Rain King.

This happens during the rain ceremonies that Henderson attends with Dahfu, the Wariri king; one by one, the smaller gods have been removed from the arena while the champions display their strenght moving the heavier gods. Looking at those superb specimens Henderson thinks: "Oh, my body, my body! Why have we never really got together as friends? I have loaded it with my vices, like a raft, like a barge. Oh, who shall deliver me from the body of this death? ("5). So, unlike the "schmuerz" in Boris Vian's play Les Bâtisseurs d'Empire, who stands for the mortal part of ourselves that we brutally flog and maltreat without noticing what we are doing $\left({ }^{46}\right)$, Henderson is aware of what he has done to his body.

Then, only two gods are left to be moved: Hummat, the 
goddess of clouds. Hummat is moved away by Turombo, the strong. man, but he lacks confidence in moving Mummah. "You know what it is?" Henderson asks Dahfu, "It's the memory of past defeats - past defeats, you can ask me about this problem of past defeats. Brother, I could really tell you. But that's what got him. I just know it" ("77).

But the invincible Henderson is ready to try again, after the defeat with the frogs. His chance had come again. He knew he could do it. He tells Dahfu: "King I am a Becomer. Now you see your situation is different. You are a Be-er. I've just got to stop Becoming. Jesus Christ, when am I going to Be?"... "So I am asking you. You've got to let me out there" $\left({ }^{45}\right)$.

Henderson lifts the goddess, and his fear is transformed into jubilation. "My spirit was awake and it welcomed life anew. Damn the whole thing! Life anew! I was still alive and kicking and I had the old grun-tu-molani" ("9).

If Henderson needed self-assertion through some spectacular deed, he had got it now. But that wasn't enough, to know he was alive. And it is through Dahfu, with his "extra shadow" ("io) around him, like all people who have a strong gift of life, that Henderson hears the most thrilling wisdom he could possibly imagine:... "I feel there is a law of human nature in which force is concerned. Man is a creature who cannot stand still under blows"... "a creature of revenges"... "when he cannot get rid of punishment, his heart is apt to rot from it"... And later on: "A brave man will try to make the evil stop with him. He shall keep the blow. No man shall get it from him, and that is a sublime ambition"... Dahfu finishes by saying: "Perhaps 1 am not the one to make a prediction, Sungo, but I think the noble will have its furn in the world" ("1).

When Dahfu dies, clawed by the lion he was hunting (supposed to be his late father, Gmilo), he is at peace. "You are the noblest guy I ever met", Henderson tells Dahfu (52). But Dahfu's nobility has already reached Henderson and changed him, for the millionaire who was running away from the horror of death is now capable of giving his heart for Dahfu, entirely and literally. Henderson is also at peace with reality, after Dahfu's death.

Back in the airplane that is taking him home, Henderson tells us: "... Dahfu will never be seen again, and presently I will never be seen again; but every one is given the components to see: the water, the sun, the air, the earth" $\left({ }^{53}\right)$.

As John J. Clayton says in Saul Bellow: In Defense of Man (54); 
Henderson has returned to his lost, childhood self, his true self. The earth is his again.

\section{Grun-fu-molani, but in what form?}

Henderson's inner voice saying "I want, I want" to him, is the polar opposite to his fear of extinction. He finds this out when he meets Queen Willatale of the Arnewi, Itelo's aunt. As soons as he touches her breast - the normal form of geeeting there - Henderson feels as if he were touching "the secrets of life". For she was a Bittah, a person of real substance, man and woman at the same time. Henderson feels so comforted just to see her that he feels his hour of liberation from chaos is drawing near, "when the sleep of the spirit was liable to burst" (jJ). She is a fountain of wisdom to him and he wants her to give him a sample of it.

What she sees in him can only be seen with an "inward eye", with her "bluish white" defective eye $\left({ }^{56}\right)$, unable to see outward things: "World is strange to a child", she tells him; "You not a child, sir?" ("5i). And Henderson, enraptured, reflects: "True, all too true. I have never been at home in life. All my decay has taken place upon a child"... "the world may be strange to a child, but he does not fear it the way a man fears. He marvels at it. But the grown man mainly dreads it. And why? Because of death" ("s).

And while he sings from Handel's "Messiah", Willatale exclaims: "Grun-tu-molani" - "Man want to live". The dawn of a new life has finally reached Henderson in Willatale's words. It was because of this "molani" that he had set out into the world. Henderson now believes there is a scheme in this world and that he can find some order and clarity in it. As Marcus Klein has pointed out in "A Discipline of Nobility" ("I), the old queen's advice, "Grun-tu-molani", man-want-to-live, comes to mean going about the business of living despite the death-dealing, chaotic Real.

The proposition is not complete, though. He wants more than reconciliation to life, "his frenzied lust for living affirming the basic value of human existence and incarnating the desire to redeem its griefs" ("6) is not enough for Henderson. And it is with King Dahfu, under his tutelage, that Henderson learns how to change from an arrested state of "becoming" into a state of "being", "the only realm in which love is possible" ("1), that Henderson learns how to distinguish "the states that are given" from "the states that are made" $\left({ }^{\prime \prime}\right)$. 
And the instrument Dahfu uses to convey his knowledge to Henderson is Atti, the lioness, "a hundred per cent within the given"

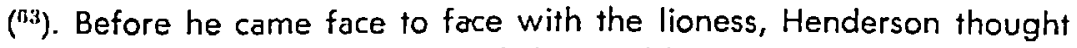
he had seen "the strangeness of the world", but "obviously, he had never even begun to see a thing!" $\left({ }^{64}\right)$. The "richness of the mixture" was too much for him.

When the lioness leaves, Dahfu tells Henderson: "Oh, Mr. Henderson - Sungo",... "this is not dreaming and s!eeping, but waking. $\mathrm{Ha}$ ! Ha! Men of most powerful appetite have always been the ones to doubt reality the most. Those who could not bear that hopes should furn to misery, and loves to hatreds, and death and silences, and so on" ("5).

Dahfu goes on: "You particularly need", he tells Henderson ( ${ }^{(6)}$ ), and he realizes that it is this "imprisoned wanl" that has made Henderson succeed with Mummah. For Dahfu, "Fear is a ruler of mankind. It has the biggest dominion of all"... "as a molding force if comes second only to Nature itself" ("i7). He tells Henderson to contemplate and absorb from Atti, for when "the fear has subsided you will be capable of admiring her beauty. This is also said of perfect love if I recollect, and it means that ego-emphasis is removed" ${ }^{(35)}$. We remember that in both tribes, Henderson has found men and women he loves and admires.

But Henderson is still running from reality, for reality is composed of beauty and terror - the lioness - and Henderson cannot res. pond to her beauty, from fear. But he agrees to become Dahfu's pupil and acts the lion, roaring on all fours. And all his sorrow comes out in the roaring. He understands Daniel's prophecy now, to Nebuchadnezzar (see page 7) $\left(^{(0)}\right)$. After this exertion, Dahfu congratulates Henderson, saying: "What could be grun-tu-molani upon a background of cows?"... ( $\left.{ }^{70}\right)$. "You are an exceptional amalgam of vehement forces" (i1)... "You flew here, into Africa. All human accomplishment has this same origin, identically. Imagination is a force of nature"... "What Homo sapiens imagines, he may slowly convert himself to" ("2). For Dahfu's sake, Henderson could change. He accepted the discipline of being like a lion, although he knew he would never make a lion; but he "might pick up a small gain here and there in the attempt" ${ }^{73}$ ). Henderson now knows that "life is not just an arena where you raise cheers by raising an idol; it is also the cellar under the palace, where beauty in the form of terror waits" (74).

As is pointed out in The Creative Present: Notes on Contemporary American Fiction $\left({ }^{75}\right)$, "Henderson discovers forces stronger than 
death in nature, in animals and in man himself". We have already seen how Henderson was changed by being in contact with Queen Willatale, King Dahfu and Atti, the lioness. Let us now see how Henderson is affected by nature, for he has already found meaning in life and an answer for death.

\section{African sunrise and Arctic daylight:}

While Henderson is preparing the bomb to exterminate the frogs, Mtalba arrives and starts courting him, modeling her clothes and dancing for him, "heavy but beautiful" (ic) and Henderson realizes, as the night and the dancing wore on, that "this was enchantment. This was poetry, which should allow to reach me, to penetrate the practical task of demolishing the frogs in the cistern". He feels what he has felt when arriving at the village - poetry, enchantment. Freed from the rubbish accumulated over the years on his soul, Henderson can enioy life at the right moment: when it presents something beautiful to him.

Henderson is beginning to see with the wonder of child's eyes the world around him. African sunrise can finally touch him with its rays, for he is convinced that things, the "object world itself" (i7) gave him a kind of go-ahead sign. He becomes aware of the light at daybreak against the white clay wall beside him. When this same color became deeper and turned into pink, Henderson at once recognizes the importanceof this "as throughout my life I had known these moments when the dumb begins to speak, when I hear the voices of objects and colors; then the physical universe starts to wrinkle and change and heave and rise and smooth, so it seems that even the dogs have to lean against a tree, shivering" (is).

He remembers having seen it as a boy, fiffy years back, in his bed, looking at the white plaster of the ceiling and outside a white shutter, covered with the same pink color. These images of dawn associated with childhood images mark the beginning of Henderson's gradual change from chaos to clarity. He is beginning to purify his soul, looking at the world with new eyes, receptive to what is beautiful around him.

He inhales the color, trying to get the most out of it, for his soul is in a state as mild as the color itself, and he says to himself: "l knew that this place was old". Meaning, he had "sensed from the first that I might find things here which were of old, which I saw when I was still innocent and have longed for ever since, for all my life - and without which I could not make it. My spirit was not 
sleeping then, I can tell you, but was saying, Oh, ho, ho, ho, ho, ho, ho!" ("70).

This image of life, of the first day of Creation, is the answer Henderson finds for the images of death that he was trying to discard from himself. The wisdom he has received from Willatale is confirmed by the light of dawn gleaming on him.

And light is the image we find at the end of the book, but not a warm African sunrise - but the cold, pure, gray, Arctic light of Newfoundland, where Henderson's plane back to America has topped for fuel. With him, a Persian orphan boy, an alien like himself, looking at the world "with two smoothly gray eyes... greatly expanded into the whites - new to life altogether. They had that new luster. With it they had ancient power, too. You could never convince me that this was for the first time". $\left({ }^{(5)}\right)$.

And it is with this image of his true self in his arms, that Henderson steps out of the airplane, inhaling pure happiness from the eternal winter of Newfoundland, as if the purity of the ice surrounding him confirmed the clarity of his state of soul, open like a child's. It was medicine for him, like the boy. He is finally a Be-er - "leaping, pounding and tingling over the pure white lining of the gray Arctic silence" ( ${ }^{(81)}$.

\section{CONCLUSION:}

Examining the stages of Henderson's spiritual progress, we see that Bellow's hero starts "in a gesture of escape from burdens, an extreme romantic gesture" (" $"$ "). This gesture takes us back to Leatherstocking and all those who leave for the woods, away from civilization. Henderson has learned from the humble Arnewi to the fierce Wariri, and from the Be-ers Willatale, Dahfu and Atti, the lioness. Henderson has reached his own conclusions, which he explains to Romilayu:

"... All the major tasks and the big conquests were done before my time. That left the biggest problem of all, which was to encounter death...". "And it's the destiny of my generation of Americans to go out in the world and try to find the wisdom of life. It just is" ("\$3).

Henderson wants to be a doctor when he gets back to America, he wants to cure the sick, for "healers are sacred" (84). He knows he can't live in the past, for it will ruin him. Dahfu's dried blood on him is taken as a symbol by Henderson, that he should try to conti- 
nue Dahfu's existence. "How? To the best of my ability. But what ability have 1 got?" ( 85 ).

Unconsciously, Henderson is going to be a Medicine-Man, something Dahfu had begun but had not finished doing. He doesn't want to accept to be king of the Wariris, because "there'll be nobody to talk to any more. I've gotten to that age where 1 need voices and intelligence. That's all that's left. Kindness and love" ( $\left.{ }^{56}\right)$.

This is what he intends to give his wife and children, when he gets back. He isn't the agony type any longer, he is wise enough now to refurn to civilization, and he comes back with a new will to creation, "for man can never commit himself too late" (5i).

The sacred lion cub he brings along, from Dahfu's tomb, serves him a double purpose: Dahfu is supposed to be incarnate in the cub, it is Dahfu resurrected, and it will consiantly remind Henderson "to act the lion".

Together with the cub and the Persian boy, an image of his childhood self, of new-acquired innocente, Henderson consummates his quest by getting back to his homeland, able again, to rejoin society, "an example of the contemporary absurd hero's possession of a new and strangely ennobling compassion" ("ii).

Henderson has not failed, it does not matter for us if, back in America, he will blunder into his same old mistakes, because he has learned that "it is the struggle itself which is his definition" ("5:).

And this much Bellow has taught us.

\section{FOOTNOTES}

1) Kazin, Alfred, "The World of Saul Bellow", Contemporaries (Boston: An Atlantic Monthly Press Book - Little \& Brown) p. 217.

2) Bellow, Saul, Honderson the Rain King (A Fawcett Crest Book, p. 7).

3) Baumbach, Jonsthan, The Landscape of Nighimare (New York University Press, 1965, p. 35).

4) lbid. p. 35.

5) Bellow, Saul, HRK, p. 7.

6) Esslin, Martin, The Theatro of Absurd (a Pelican Bock), Revised and Enlarged Edition, 1970, p. 147.

7) Bellow, Saul, HRK, p. 80

a) Esslin, p. 391 .

9) Bellow, Saul HRK, p. 20.

10) Ibid.

11) Ibid.

12) Ibid. p. 37. 
13) Ibid. p. 37.

14) Esslin, p. 392.

15) Bellow, Saul, HRK p. 23.

16) Ibid. p. 8.

17) Esslin, P. 153.

18) Galloway, David D., The Absurd Hero, Proface to first edition, (Univ. of Texas Press, Austin \& London, 1970).

19) Bellow, Saul, HRK p. 23.

20) Ibid. p. 24.

21) Ibid. p. 25.

22) Ibid. p. 41.

23) Ibid. p. 41.

24) Ibid. p. 44.

25) Ibid. p. 45.

26) Ibid. p.46.

27) lbid. p. 48.

28) lbid. p. 49 .

29) lbid. p. 54.

30) Ibid. p. 54.

31) Ibid. p. 57.

32) Ibid. p. 60.

33) Ibid. p. 61 .

34) Ibid. p. 61.

35) lbid. p. 62.

36) lbid. p. 62.

37) Hassan Ihab, Radical Innoconce: Studios in the Contemporary American Novel, Princeton Univ. Press, 1961, p. 317.

38) Bellow, Saul, HRK, p. 77.

39) Ibid. p. 77.

40) Ibid. p. 78.

41) Ibid. p. 91.

42) Ibid. p. 96.

43) Ibid. p. 117.

44) Ibid. p. 119.

45) Ibid. p. 155.

46) Esslin, p. 241.

47) Bellow, Saul, HRK, p. 157.

48) Ibid, p. 162.

49) Ibid. p. 164.

50) lbid. p. $176-7$.

51) Ibid. p. 182.

52) Ibid. p. 262.

53) lbid. p 279.

54) Clayten, John J., Saul Ballow: In Defonse of Man, Indiona Univ. Press, 1968, p. 184.

55) Bellow, Saul, HRK p. 70.

56) lbid. p. 64. 
57 Ibid. p. 73.

58) lbid. p. 74.

59) Klein, Marcus, A Discipline of Nobility: Saul Bellow's Fiction (The Aflantic Monthly Press) p. 203-226.

60) Hassan, Ihab, p. 319.

p. 319.

61) Jbid. p. 319.

62) Bellow, Saul, HRK p. 221.

63) Ibid. p. 221.

64) lbid. p. 192.

65) Ibid, p. 196.

66) Ibid. p. 197.

67) Ibid. p. 218.

68) Ibid. p. 221.

69) Ibid. p. 194.

70) Ibid. p. 227.

71) lbid. p. 228.

72) ibid. p. 229.

73) Ibid. p. 250.

74) Clayton, John H. p. 250.

75) The Creative Present: Notes on Contemporary American Fiction, Edited by Nona Balakian and Charles Simmons, (Doubleday \& Co. Ine. Garden City. New Yark) 1963.

76) Bellow, Soul HRK, p. 85.

77) lbid. p. 86

78) Ibid. p. 87.

79) Ibid. p. 88.

80) lbid. p. 285.

81) Ibid. p. 286.

82) Klein, Marcus, p. 211.

83) Bsllow, Saul HRK, p. 233.

B4) Ibid. p. 240.

85) Ibid. p. 264.

86) Ibid. p. 265.

87) Hassan, Thab, p. 320.

88) Galloway, D.vid D., p. 11.

89) Bcilow, Saul HRK, p. 123. 